\title{
EARTHQUAKE DISASTER OF YOGYAKARTA AND CENTRAL JAVA, AND DISASTER REDUCTION, INDONESIA
}

\author{
Sutikno \\ Faculty of Geography, Gadjah Mada University, Yogyakarta, Indonesia \\ Research Centre for Disaster, Gadjah Mada University, Yogyakarta, Indonesia \\ E-mail: sutikno_geougm@yahoo.com
}

\begin{abstract}
Wis paper discussed on earthquake disaster and its reduction of Yogyakarta and Central Java, Indonesia. The study area is located at relatively a short distance from subduction zone of India-Australian and Eurasian plates. Geologically this area is characterized by fault and graben structure, and geomorphologically is composed of block mountain, karsts topography and fluvio-volcanic plain. Aim of this paper is to evaluate the spatial distribution of the damage area, the environmental impacts, and to discuss the risk reduction of earthquake disaster scientifically and practically. In this paper to determine the hazard susceptibility zone and their environmental impact used geologic, geomorphologic, land use map, remote sensing image interpretation, and field observation. Discussion on the earthquake disaster risk reduction based on the hazard susceptibility and the characteristic of the buman settlement and facilities. The result of this study shows that: i).the bigh damage area associate with distribution of the fault structures and the lithology; ii). mass-movement, lowering of groundwater, rising new springs, liquefaction, cracking of rocks and land surface; iii). structural non structural efforts are used for earthquake disaster reduction.
\end{abstract}

Keywords: earthquake disaster, environmental impact, structural and non structural effort for reduction

\section{INTRODUCTION}

Last three years Indonesia was hit by several types of disasters, such as: earthquake in Aceh (2004), Nias (2005), Yogyakarta, Central Java, and West Java (2006); volcanic eruption in Yogyakarta (2006); flood in Java, Kalimantan, Sumatra, Sulawesi (2004, 2005, 2006); hot mud in East Java (2006); mass-movement (landslides) in Java, Sumatra, Sulawesi (2004, 2005, 2006). There are some geographical situations that influence why Indonesia region is susceptible to many type of disasters, because the location is: in collide of three huge plate tectonics (Eurasian, India-Australian and Pacific plates), between two oceans (Pacific and Indian), and between two big continents (Australian and Asian). The effects of the collide plates, the region become active tectonic and active volcanic as well. The active tectonic related to some hazard or disasters such as earthquake, tsunami, fault, uplift, subsidence and mass-movement. While the active volcanic region associated with some type of hazards or disasters such as: volcanic eruption, pyroclastic rain, nue ardente, lahars flow and toxic gas, there are for about 129 active volcanoes in Indonesia. The Merapi which is located in the northern part of Yogyakarta is the most active volcano in Indonesia. The effects of the location in between two oceans and two continents, Indonesia has wet tropical climate. It associates with active exogenous processes, which may cause flood, mass-movement (landslides), erosion, drought and fire. It can simply state that Indonesia is very rich in disaster (Sutikno, 2006). 
Earthquake on $27^{\text {th }}$ May 2006 has devastated southern part of Yogyakarta Special Region and east-southern part of Central Java Province. The Yogyakarta Special Region is a province that consists of five districts: Bantul, Yogyakarta, Sleman, Gunungkidul and Kulon Progo. Among those districts the most damage areas are Bantul, southern part of Sleman, southern part of Yogyakarta municipality and western part of Klaten district (it belong to Central Java Province). Yogyakarta Special Region and Central Java Province is located in Java Island. The Java Island is a part of Indonesia territory among 17.508 islands. Most of the islands are characterized by tectonic and volcanic activity, and humid tropic climate. That is why most part of Indonesia is prone to so many types of natural disaster, such as flood, drought, landslide, earthquake, volcanic eruption, and tsunami. The tectonic and volcanic activities in Indonesia are caused by the location in the collision of three huge plate tectonics: India-Australia, Pacific and Eurasia. The study area is located in the collision between India-Australian and Eurasian plate (Fig. 1).

When the $27^{\text {th }}$ May 2006's earthquake occurred, it was accompanied by thundering sound, most people of Yogyakarta supposed that the thundering sound come from the Merapi volcano eruption (it is located in the northern part of Yogyakarta), because at that period the Merapi volcano was erupting. Fifteen minutes after the thundering sound, the real event was known as earthquake that epicenter is located in the southern part of Yogyakarta, precisely near by the mouth of Opak River. There was tsunami issue at that time as occurred in Aceh on $27^{\text {th }}$ December 2004, by the issue the traffic condition of Yogyakarta and its surrounding was very crowded. People from the northern part went to the south because afraid from Merapi eruption, and reversely because afraid of tsunami; some traffic accidents occurred and it caused injury and death. ${ }^{\text {ththt }}$ Earthquake disaster on $27^{\text {th }}$ May 2006 with magnitude 5.9 SR (BMG) or 6.3 (USGS) caused large number of victims, houses and public facilities damage. Actually the magnitude of the earthquake is in medium scale, but it is not comparable with the number of the victims and the loss of properties. This condition invites a question and interest to discuss. There are three problems will be discussed here: i). why the study area has a high susceptibility to earthquake disaster and high vulnerability; ii). what is the environmental impact of earthquake disaster; iii). what kinds of reduction program to anticipate the probable disaster in future?

\section{DATA AND METHOD}

The earthquake in Yogyakarta and Central Java was caused by tectonic activity, and was triggered by disturbing of the subduction zone between India-Australian and Eurasian plates. Relating to tectonic type's of earthquake, geological, geomorphological, hydrological data are needed to evaluate the disaster susceptibility, while land use data are needed for damage assessment. Geological, geomorphological and hydrological data are obtained by map and remote sensing interpretation (manually) and field observation. The existing geological map in scale 1:100,000 scale and Landsat TM in 1:250.000 scale was used to identify the lithology, the geological structure and landform condition that promote the earthquake disaster. The existing topographic map in 1:50,000 scale and 
IKONOS bird images before and after earthquake were used to identify of land use type and to evaluate the damages. Field observation on purposive framework was carried out to determine the actual damages and to estimate the environment impact on the physical aspect. Based on the bio-geophysical, the actual damage, the land use types data, the geographical location of the study area, and integrate to the local government program an idea to reduce for the disaster in future is formulated.

\section{Geology and Geomorphology of Yogyakarta and Its Surrounding}

In global scale Yogyakarta and its surrounding are located on the Sunda Mountainous System, which is characterized by non-volcanic arc and volcanic arc (Verstappen, 2001). The Sunda Mountainous system is extension of the Eurasian plate; it is bounded to the Indian-Australian plate. The margin of the plates are in collision, resulting in the consumption of plates along subduction zone, the creation of volcanic arcs and compression of oblique slip structure (Darman and Hasan Sidi, 2000). The collision of the plates and the subduction zone become a concentration of seismic activity and tectonic activity as well (Summerfield, 1991; McGeary, et al., 2004; Abbott, 2004). Due to Yogyakarta and it surrounding are located near by the collision of the Eurasian and Indo-Australian plates, geological and geomorphologic condition of the area is characterized by tectonic origin. The geologic and geomorphologic condition of the study area shortly is described below.

Based on the geological condition, the study area can be distinguished into three parts: east, middle and western parts. Boundary between the middle part and eastern is Opak River, while the middle and western part bordered by Progo River. Each parts has specific in lithology, geological structure and geomorphological condition, as follow.

\section{Geology and Geomorphology of the Eastern Part}

Structurally the eastern part is block hilly to mountainous area; in the west side bordered by major Opak fault in SE direction; in northern part bordered by Batuaragung fault in EW direction. Some minor faults occur in EW-SW direction (Fig. 2). The fault pattern in eastern part associated with the spatial distribution of the damage area due the earthquake disaster. The damage area beside associated with the fault structure are also influenced by the lithology. The lithology of the eastern part composed of six unit/formations: alluvium, Wonosari, Kepek, Sambipitu, Nglanggran and Semilir formation:

1) Alluvium: composed of sand, loam and clay as weathering and erosion product from the existing rock formation; the topography is flat to gently and the landform unit is alluvial plain and foot slope.

2) Wonosari formation (Miocene): composed of reef limestone, calcarenite and tuffaceous calcarenite; it forms karsts topography which is characterized by conical hills, doline, underground stream and caves; due to the large number of the conical hill it is known as Gunungsewu (thousand mountains). The structure is plateau and the dip for about $8^{\circ}$ to the South. (to India Ocean), and the altitude $0-450 \mathrm{~m} \mathrm{msl}$. 
3) Kepek formation (Miocene): composed of marl and bedded limestone; the topography is undulating and the structure is syncline; the landform unit is undulating syncline topography.

4) Sambipitu formation (Miocene): composed of tuff, shale, sandstone and conglomerate; dip of the layer $8^{0}$ locally in NE direction; topography is hilly.

5) Nglanggran formation (Miocene): composed of volcanic breccia, flow breccia, agglomerate, lava and tuff; the topography is hilly with steep slope, the altitude in between $200-500 \mathrm{~m}$ msl.

6) Semilir formation (Miocene): composed of interbedded tuff breccia, pumice, dacite tuff and andesite tuffs and tuffaceous claystone; dip of layer 14-22 and the strike mainly to $\mathrm{NE}$ and some minor fault occur in EW and NE direction ; the topography mostly is hilly, the altitude mostly less than $200 \mathrm{~m}$ msl. (Wartono Rahardjo et al., 1995).

Among those lithological/formation units that much were influenced by the $27^{\text {th }}$ May 2006's earthquake were alluvium, Semilir, Nglanggran, and Wonosari formation. It was caused by the characteristic of the rocks properties, the geological structure, the distant from the fault and the distant from the epicenter of the earthquake.

\section{Geology and Geomorphology of the Middle Part}

Structurally the middle part is graben and it is called by Bantul graben. East side of the graben is bordered by Opak fault and the west side is bordered by Progo fault. Lithology of the middle part com- posed of alluvium, young volcanic product and Sentolo formation (Wartono Rahardjo et al., 1995). The alluvium consist of sand on coastal sand dune, and sandloam of the back swamp landform unit. The back swamp formed in between natural levee of Opak river in west side, hilly area in eastern side and sand dune in the southern side. The young volcanic product composed of sand to loamy sand as product of the Merapi volcano. Geomorphologically the young volcanic product is located on volcanic foot plain and fluvio volcanic foot plain. The Sentolo (Miocene) formation consist of limestone and marly sandstone. Comparing with the limestone of the Wonosari formation, the karsts topography in the Sentolo formation is less develop. Relating to the $27^{\text {th }}$ May 2006's earthquake disaster the most damages area in the middle parts was on the volcanic foot plain and the fluvio-volcanic foot plain. The reason is the material composition of the middle parts is unconsolidated material, the groundwater at shallow depth and the area is near by the earthquake epicenter .

\section{Geology and Geomorphology of the Western Part}

Structurally the western part as whole is dome like mountainous, with radial fault pattern, it is known as West Progo Mountain. The lithology/formation of the West Progo Mountain consist of alluvium, Sentolo formation (Miocene), Jonggrangan formation (Miocene), Kebobutak formation (Miocene), Nanggulangan formation (Eocene) and Andesite (Wartono Rahardjo et al., 1995). The alluvium consist of two types the first is sand from beach ridges, and the second sand to clay from alluvial plain and back-swamp. The Sentolo formation composed of limestone and marly 
sandstone., and Jonggrangan formation composed of conglomerate, tuffaceous marl and calcareous sandstone with intercalation by lignite seams, limestone and corraline limestone. Kart topography in the Jonggrangan limestone is more well develop compare to the Sentolo limestone. The Kebobutak formation composed of andesite breccia, tuff, lapilli tuff, agglomerate and intercalation by lava flows. Andesite is located in the centre of West Progo Mountain and together with the Kebobutak formation supposed to be product of old volcano (Tertiary). The oldest formation in the western part is Nanggulan that composed of sandstone with intercalated by lignite, sandy marl, claystone with limonite concretion, intercalations of marl and limestone, sandstone and tuff.

Based on the geological and geomorphological condition, the study area has dynamic development. It means that tectonic and volcanic activities has been occurred several time in the study area. The major fault of Opak and Progo and the associated minor fault, uplifting of marine deposits such as limestone of the Wonosari, Sentolo and Jonggrangan formations must be caused by tectonic activity and accompanied by earthquake. Naturally the study area are prone to earthquake disaster, due to the local people and the local government do not aware yet about the condition the toll by the last earthquake is too high compare to the magnitude of the earthquake. Death from earthquakes are mostly due to building failures, and earthquake do not kill, but building do (Abbott, 2004).

\section{Land use Type}

Based on the Landsat TM and IKONOS images the land use types in the study area can be distinguished into: rice field, dry agricultural land, settlement, forest, plantation and bare land. Spatial distribution of the land use types do not separate sharply into certain zone, but uneven distributed. The rice fields dominantly are distributed on volcanic foot plain, fluviovolcanic foot plain and alluvial plain units of the middle part, while the dry land, plantation and forest are distributed on hillymountainous units of the eastern and western part.

The settlements are distributed on various landform units, and especially on volcanic foot plain, fluvio-volcanic foot plain and alluvial plain unit. Based on the function and the facilities, the settlement can be distinguished into urban, peri-urban and rural area. In the study area that hit by the earthquake there are two main urban areas, namely Yogyakarta and Bantul. The peri-urban area is located between urban area and rural areas. Accessibility between urban, peri-urban and rural areas is good, that is why the study area has high population density. In general most part of the houses in the peri-urban and rural areas are old, simple building, one floor, without good concrete and tile roof. The such types of the houses have high vulnerability to earthquake.

\section{RESULT AND DISCUSSION}

\section{Historical Information of Earthquake Disaster}

Historically Yogyakarta area and its surrounding has been occupied for along time before the $7^{\text {th }}$ century. It proved by the existing of the ancient archaeological sites (272 sites) of Hinduism-Buddhism period which were found in the area between two main 
rivers in Yogyakarta, e.g. Progo river in the west site and Opak river in the east. Most artifacts of the archaeological sites are damage, due to volcanic activities if are located in the volcanic area, and caused by earthquake if are located at block faulting hilly area. Some of the artifacts were found few meters below the land surface such as Sambisari temple in Kalasan. The ruins temple of Candi Boko at Baturagung range that located along Opak fault could be caused by earthquake. The information above shows that Yogyakarta area and its surrounding several times have experiences hit by natural disasters (Sutikno, 2006).

Natural disaster in certain area usually has recurrent interval, even with different in the magnitude and intensity. As have been occurred in southern part of Yogyakarta (in Bantul) earthquake in the year of 1876 devastated 372 houses and 5 persons died; in 1943 there were 2.800 houses damaged and 213 persons died (Sutikno, 2006)

\section{Earthquake on the $27^{\text {th }}$ May 2006}

Most earthquakes are caused by fault movement associated with tectonic plates, the largest number of great earthquake occurred in the subduction zone of the collision of tectonic plates (Abbott, 2004; McGeary et al., 2004). The case of the $27^{\text {th }}$ May, 2006's earthquake in Yogyakarta and Central Java are also caused by fault movement that triggered by energy from the subduction zone between Eurasian and IndoAustralian plates. The magnitude of the earthquake is 5.9 Richter Scale (RS) according to BMG (Geophysical and Meteorological Agency of Indonesia) and 6.3 Richter Scale according to USGS (United Stated Geological Survey), the depth of the epi- center is $33 \mathrm{~km}$ and located near by the mouth of the Opak river (Fig. 3), at $9.78 \mathrm{~S}$ and 110. $32 \mathrm{E}$ (UTC).

The magnitude of the earthquake in the study area is classified as medium scale. The magnitude of earthquake usually correlate with the length of shaking, if the magnitude 5- 5.9 RS the duration of strong ground shaking is $2-15$ seconds, and the magnitude is 6-6.9 RS the duration 10-30 seconds (Abbott, 2004).

The duration of strong shaking of the Yogyakarta's earthquake rather exception because the duration took time for about 55 seconds. After shock, there were many accompanied earthquake or ground shaking occurred. Based on the recording data from BMG after shock of the main earthquake, the frequency of the accompanying earthquakes at the same day was still large enough, and tend to decrease for the next day even for the next month (Table 1). The magnitude of the accompanying earthquakes mostly less than 2,9 RS at the depth $10 \mathrm{~km}$. At May $27^{\text {th }}, 2006$, after shock there were 110 ground shaking that consisted of : 90 times at $<2,9$ RS; 18 times at 3-3,9 RS and 2 times at 4-4,9 RS. In June 2006, the accompanying earthquakes still occurred, but the frequency decreased; there were 60 times that consisted of 49 at $<2.9$ RS; 9 at 3-3.9 RS and 2 at 4-4.9 RS. From May $27^{\text {th }}$ until the end of June 2006, there were 170 accompanying earthquake, and fore about $74 \%$ occurred at $10 \mathrm{~km}$ depth. The epicenter of the accompanying earthquakes are located around the main earthquake at the range of 110,03 - 110, $59 \mathrm{E}$ and 7,3-8,33 S. Relating to the accompanying earthquakes there were evens that un sufficiently explanation; before accompanying earthquakes occurred always started or begun 
Table 1. Accompanying Earthquakes after Shock of May 27 ${ }^{\text {th }}, 2006$

\begin{tabular}{|c|c|c|c|c|c|c|c|c|c|c|c|c|}
\hline \multirow{3}{*}{$\begin{array}{l}\text { Month } \\
\text { and date }\end{array}$} & \multicolumn{12}{|c|}{ Magnitude and the depth of epicenter of the accompanying earthquakes } \\
\hline & \multicolumn{3}{|c|}{ Magnitude : $<2.9$} & \multicolumn{3}{|c|}{ Magnitude: 3-3,9 } & \multicolumn{3}{|c|}{ Magnitude: $4-4,9$} & \multicolumn{3}{|c|}{ Magnitude: $5-5,9$} \\
\hline & $\begin{array}{l}10 \\
\mathrm{~km}\end{array}$ & $\begin{array}{l}20 \\
\mathrm{~km}\end{array}$ & $\begin{array}{l}30 \\
\mathrm{~km}\end{array}$ & $\begin{array}{l}10 \\
\mathrm{~km}\end{array}$ & $\begin{array}{c}20 \\
\mathrm{~km}\end{array}$ & $\begin{array}{l}30 \\
\mathrm{~km}\end{array}$ & $\begin{array}{l}10 \\
\mathrm{~km}\end{array}$ & $\begin{array}{l}20 \\
\mathrm{~km}\end{array}$ & $\begin{array}{l}30 \\
\mathrm{~km}\end{array}$ & $\begin{array}{l}10 \\
\mathrm{~km}\end{array}$ & $\begin{array}{r}20 \\
\mathrm{~km}\end{array}$ & $\begin{array}{l}30 \\
\mathrm{~km}\end{array}$ \\
\hline May, $27^{\text {th }}$ & 49 & 3 & 3 & 7 & 2 & 6 & 1 & 1 & 0 & 0 & 0 & 1 \\
\hline May, $28^{\text {th }}$ & 6 & 1 & 5 & 1 & 0 & 0 & 0 & 0 & 0 & 0 & 0 & 0 \\
\hline May,29th & 10 & 1 & 0 & 2 & 0 & 0 & 0 & 0 & 0 & 0 & 0 & 0 \\
\hline May,30rd & 7 & 1 & 0 & 0 & 0 & 0 & 0 & 0 & 0 & 0 & 0 & 0 \\
\hline May,31 ${ }^{\text {st }}$ & 2 & 1 & 1 & 0 & 0 & 0 & 0 & 0 & 0 & 0 & 0 & 0 \\
\hline $\begin{array}{l}\text { Total } \\
\text { May }\end{array}$ & 74 & 7 & 9 & 10 & 2 & 6 & 1 & 1 & 0 & 0 & 0 & 1 \\
\hline $\begin{array}{l}\text { June, } \\
20006\end{array}$ & 45 & 2 & 2 & 6 & 0 & 3 & 1 & 0 & 1 & 0 & 0 & 0 \\
\hline
\end{tabular}

Data analysis of BMG record, 2006

with look like boom sound, after the sound then followed by shaking. The sound heard by people who live at the surrounding faulted area.

Based on the large number of the accompanying earthquakes after shock it means that the area is still in labile condition. It is caused by the existence of the Opak fault and the accompanying faults. The faults were reactivated by the earthquake on May $27^{\text {th }}, 2006$. Due the location of the Opak fault near by and faced to the collision of the tectonic plates and the study area above the subduction zone, the reactivated fault will occur in future. The study area still has high susceptibility to earthquake hazard and its associated impact.

\section{Impact of the Earthquake of Yogya- karta and Central Java}

Ground motion or land shaking by earthquakes have some kind of impacts, such as damage of building and infrastructures, fire, landslide, liquefaction and per- manent displacement of the land surface (McGeary et al., 2004), and tsunami if the epicenter is located in the ocean/floor with medium to high magnitude of the earthquake. The intensity impact of the earthquake depends on several variables, such as magnitude, distance from the hypocenter/epicenter, types of rocks or sediment making up the ground surface, building stile, design, kind of building material and height, and duration of the shaking (Abbott,2004). Regarding to the geologic and geomorphologic condition, land use type, building characteristics, the magnitude and duration of the earthquake some impacts of the earthquake of Yogyakarta and Central Java can be identified, such as: building and houses damages, infrastructure damages, liquefaction, landslide and displacement of the land surface.

\section{Damage of Houses, Buildings, and Fa- cilities}

Due to the long shaking duration of the main earthquake (55 seconds) on 5.9 RS at $33 \mathrm{~km}$ depth, that occurred on com- 
plexes faulted area, partly composed of various rocks/sediment and dense populated area may caused higher victims and damages. A large number of accompanying earthquakes at shallow depth also have psychological influences to the people in the stricken area. Damage assessment of any disaster in large area usually get difficulties, because of accessibility of the remote area and transport facilities. Table 2 show temporary data of the victims and Table 3 show the damages due to the earthquake in Yogyakarta, in one week after shock. The data do not cover yet the victims and the damages from Klaten district of the Central Java Province. The recent data show that the number victim 5,048 died, 206,524 houses damage, 2,014 small and medium industries damages, 2,371 school building and the financial loss for about 22 trillions rupiahs ( $\$ 2,100$ millions).
The number of victims and damage houses in Bantul are much higher compare with the others, because of the location is relatively close to the fault complexes, dense populated area and poor the building quality. Up to now some people still live in tends, as a reason the rehabilitation and reconstruction programs of the houses do not finish yet, and they still trauma with the earthquakes occurrences. Beside the houses, some public facilities such as school building, road and water supply also damaged. Figure 4 shows spatial distribution of damage areas in relating to geological condition (Murwanto et al., 2006).

\section{Landslides due to Earthquake}

Naturally the study area has medium to high landslide hazard susceptibility. It is supported by some factors, such as geo-

Table 2. Victim data of earthquake disaster of Yogyakarta ( data on June $2^{\text {nd }}, 2006$ )

\begin{tabular}{|c|l|r|r|r|}
\hline \multirow{2}{*}{ Num. } & \multirow{2}{*}{ District } & \multicolumn{3}{|c|}{ Number of victims } \\
\cline { 2 - 5 } & Bantul & 227,030 & 77,251 & \multicolumn{1}{c|}{ Persons } \\
\hline 1 & Yogyakarta & 48,244 & 195,456 & 178 \\
\hline 2 & Kulon Progo & 18,081 & 74,592 & 22 \\
\hline 3 & 45,127 & 13.543 & 224 \\
\hline 4 & Sleman & - & - & 84 \\
\hline 5 & Gunung Kidul & 338,482 & $1,201,895$ & 4,629 \\
\hline & Total & &
\end{tabular}

After Sutikno, 2006

Table 3. Damage data of houses and education facilities due to earthquake disaster of Yogyakarta (data on June $2^{\text {nd }}, 2006$ )

\begin{tabular}{|r|l|r|r|r|r|}
\hline \multirow{2}{*}{ Num. } & \multirow{2}{*}{ District } & \multicolumn{3}{|c|}{ Houses damage } & \multicolumn{1}{c|}{$\begin{array}{c}\text { Educational } \\
\text { facilities } \\
\text { damage }\end{array}$} \\
\cline { 3 - 5 } & $\begin{array}{c}\text { Totally } \\
\text { damage }\end{array}$ & $\begin{array}{c}\text { Highly } \\
\text { damage }\end{array}$ & $\begin{array}{c}\text { Slightly } \\
\text { damage }\end{array}$ & 158 \\
\hline 1 & Bantul & 71,482 & 70,718 & 66,497 & 386 \\
\hline 2 & Yogyakarta & 7,161 & 14,536 & 21,192 & 662 \\
\hline 3 & Kulon Progo & 4,477 & 5,176 & 8,999 & 130 \\
\hline 4 & Sleman & 4,991 & 15,382 & 11,220 & 84 \\
\hline 5 & Gunung Kidul & 13,543 & 4,716 & 16,742 & 1,470 \\
\hline & Total & 101,654 & 110,530 & 124,650 & \\
\hline
\end{tabular}


logic, geomorphologic, climatologically and land use type condition. By shaking of the main earthquake some actual landslides occurred in the hilly-mountainous area; rock falls, landslide and slumping were identified. Beside the actual, some potential landslide also are identified, especially on the area where the land surface or the rocks surface show some fractures. The such condition should be take into account when the rainy come. The spatial distribution of the mass movement mainly on the steep slopes, along fault lines and along fault line scarps.

\section{Liquefaction}

Liquefaction features or sand blows, occur when ground shaking during an earthquake liquefies a subsurface layer of sand which penetrates into/or through an overlying, otherwise impenetrable layer. The overlying layer is intruded via a sand dike and if this layer is the uppermost stratigraphic unit the liquefied sand can penetrate to the ground surface and can be expressed as mound or area of sand. The original ground surface is commonly depressed as a result of the displacement of the subsurface sand and water (Bryant, 2005). During the Yogyakarta's earthquake some liquefaction features occurred, especially on alluvial plain, volcanic foot plain and fluvio-volcanic foot plain units. Features of liquefaction in the study area are shown by sand blows to the land surface and sand blows through well. In certain area the sand blows can produce one truck of sand, and the sand blows trough well, the become shallower and it can not be used for domestic water supply anymore. Liquefaction is known to occur repeatedly at the same site during more than one earthquake, and the maps showing locations of past liquefaction occurrences are very useful to delineate and characterize areas of liquefaction susceptibility for the future earthquakes (Wakammatzu,2000).

\section{Displacement of the Land Surface}

Another features as impact of the earthquakes are displacement on the land surfaces. Displacement of the land surface can be shown by fracture or fault on the hard rocks and or on unconsolidated sediment. The displacements usually have impact to groundwater condition, land subsidence and landslide. Lowering of the groundwater level up to 4 meters occur in southern part of the area, while in another sites new springs or seepage rise.

\section{Disaster Reduction}

In disaster management framework, risk reduction is important aspect. Disaster risk reduction is an effort to minimize the victim, property lost and environmental damages. Prevention, mitigation and preparedness is component of the disaster management to reduce the victims, the property and the environment before the disaster occur. Relief, rehabilitation and reconstruction is component of the disaster management during and after the occurrence of disaster.

Reduction of earthquake disaster need hard effort, because the occurrence of the earthquake can not be predicted accurately and early warning system in some cases is difficult to execute. Mitigation is the effective way to reduce the impact of the earthquake disaster. Mitigation of the earthquake disaster can be carried out by structural and non structural efforts. 
Structural effort to earthquake disaster risk reduction is less effective than non structural, because safety of building structure is depends on magnitude of the earthquake. Building regulation is needed to fulfill the minimum requirement for safety from a certain earthquake magnitude that usually occur in the prone area. Structural efforts for rehabilitation of the damage houses in this area used building regulation guided by local government. Rehabilitation of damage houses organized and carried out in a group of people who their houses were damage and each group was guided by a supervisor. Financial support for rehabilitation come from the government. At present the rehabilitation the houses do not complete yet.

Non structural effort to earthquake disaster reduction usually used possible warning indicator, land use regulation, relocation of communities, public awareness and education program. Warning indicator for earthquake, beside using seismograph record can used natural indicator. The natural indicator for earthquake commonly used bio-indicator, groundwater level changes, electric resistivity of groundwater, rock cracking and earthquake cloud. The such natural indicator did not take into account by the community, because for along time there was no occurrence of significant earthquakes. Such as a vertical cloud feature in the southern side of the stricken area above the Indian ocean three days before earthquake was meaningless by the community. After earthquake shaking the area people just aware that specific cloud feature as indicator for earthquake.

Land use regulation and relocation program was rather difficult to execute in this area, because the stricken areas have been occupied for along time, dense popu- lated area and most of the people relatively poor in financial. Relating to the land use regulation, there was local wisdom in reduction of earthquake. The local wisdom told orally by old generation that the younger generation should not build a house near by the river and should not used bricks material. This local wisdom was important meaning for risk reduction because if build the house near by the river faced with flood and earthquakes disaster, because most of the rivers in the southern part associated with fault. The faults in this area have high susceptibility to earthquake hazard.

Public awareness of the community to the earthquake disaster commonly were very low, because they did not have experienced with disastrous earthquakes. After the occurrences, the community just aware that the area where they live were located in the earthquake hazard zone. The public awareness grew by experiences and socialization that carried out by government agency, university, research center and NGO. Gadjah Mada University (GMU) is the biggest university in Yogyakarta and Central Java has important contribution to risk reduction on earthquake disaster. More than 2 thousand of the GMU's students and guided by lecturer gave socialization to the community how to mitigate the earthquake disaster. The target of the socialization are the community members and pupils from primary to high school. Education program was the effective way for socialization on risk reduction of disaster. At national level, government proposed curricula on disaster in educational program, but at temporary inserted into geographic course. In risk reduction of earthquake disaster or any types of disaster, public awareness and educational program is more effective than the others. It is not essay to maintain the aware- 
ness of the community, commonly disaster is very vast to forget. In the earthquake disaster prone area it is important to maintain of socialization program for risk reduction, because the recurrent interval for earthquake take long time.

\section{CONCLUSIONS}

Discussing on the geologic, the geomorphologic, the land use condition, earthquake characteristics and its impact of Yogyakarta and Central Java disaster this paper concluded that:

1. disturbance of subduction zone of the Eurasian and the Indian-Australian plates triggered earthquake and caused reactivated of the Opak fault system then shook Yogyakarta and Central Java; geologically and geomorphologically southern part of Yogyakarta and east-southern part of Central Java as prone area to earthquake hazard; the damages areas associated with the fault system;

2. the magnitude and the duration of the earthquake do not the only caused of the large number of victims and property lost but the structure and the material of building did; the duration of earthquake shaking caused the larger number of victims and property lost more than the earthquake magnitude;

3. the main and the accompanying earthquakes have multi-hazard impacts to the environment such as landslide, liquefaction, groundwater depletion and raising spring and seepages;

4. due to dense populated area and the marginal condition of the financial support rather difficult to make land use regulation and relocation for risk reduction from the earthquake disaster;

5. awareness and education program for the community more effective to mitigate the earthquake disaster; socialization program for risk reduction was important to maintain continually, because disaster very past to forget.

\section{ACKNOWLEDGEMENTS}

The writer gratefully acknowledges to Mr. Jaya Murjaya for supporting earthquake data, to Mr. Helmy Murwanto, Mr. Sutarto, Mr. Tono Saptono for supporting the geological information relating to the earthquake; Mr. Danang Sri Hadmoko for preparing the English version of the geological map. Last but not least thanks to Professor Haruyama Shigeko (Tokyo University) who gave a chance to joint symposium on natural disaster.

\section{REFERENCES}

Abbott,P.L. 2004. Natural Disaster. McGraw Hill. Higher Education. Boston.

BMG,2006. Characteristics of Earthquake Data of Yogyakarta Unpublished.

Bryant, E. 2005. Natural Hazards. Cambridge University Press. Cambridge.

Darman Herman and Hasan Sidi. F. (Edit). 2000. Outline of the Geology of Indonesia. IAGI. Jakarta. 
Hardjono, I. 2006. "Hirarki Gempa Bumi dan Tsunami (Aceh, Nias, Bantul, Pangandaran, dan Selat Sunda)". Forum Geografi, Vol. 20, No. 2, Desember 2006. Hlm 135-141.

Murwanto, H; Sutarto; Joko Susilo. 2006. Tinjauan Geologi. Dampak Gempa Tektonik terhadap Pola Rekahan dan Hancuran di Wilayah Jawa Tengah dan Daerah Istimewa Yogyakarta. Workshop. UPN. Yogyakarta.

McGeary,D. Plumer,C.C. and Carlsons, D.H. 2004. Physical Geology. Earth Revealed. McGraw Hill. Higher Education. Boston.

Sudarmadji. 2006. "Perubahan Kualitas Airtanah di Sekitar Sumber Pencemar Akibat Bencana Gempa Bumi”. Forum Geografi, Vol. 20, No. 2, Desember 2006. Hlm 99119.

Summerfield, M.A. 1991. Global Geomorphology. Longman Scientific\&Technical. New York.

Sutikno, 2006. Disaster Management and Holistic Approach in Planning for Peri-Urban Area Development. International Seminar on Regional Planning for Disaster Prone Areas in South East Asia. November 20-24-2006. Gadjah Mada University. Yogyakarta.

Verstappen, H.Th.2000. Outline of the Geomorphology of Indonesia. ITC. Enschede. The Netherlands.

Wakamatzu, K. 2000. Liquefaction History, 416-1997, in Japan. Institute of Industrial Science, University of Tokyo, Japan.

Wartono Rahardjo, Sukandarrumidi, Marno Datun, 1995. The Geological Map of Yogyakarta. Directorate of Geology. Bandung. 


\section{Appendix}

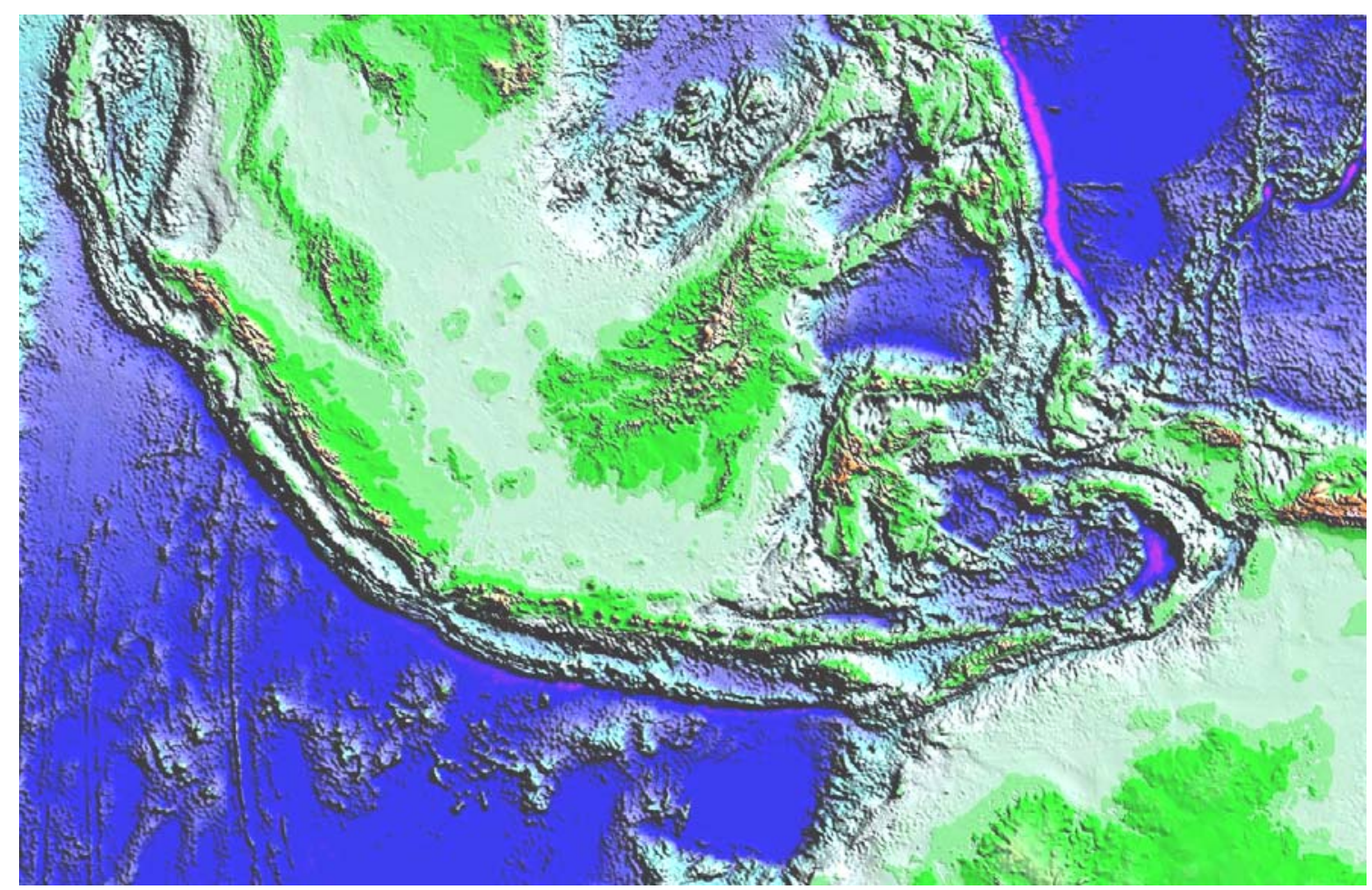

Fig.1. Location of Yogyakarta Earthquake and Central Java in Tectonic Plate 


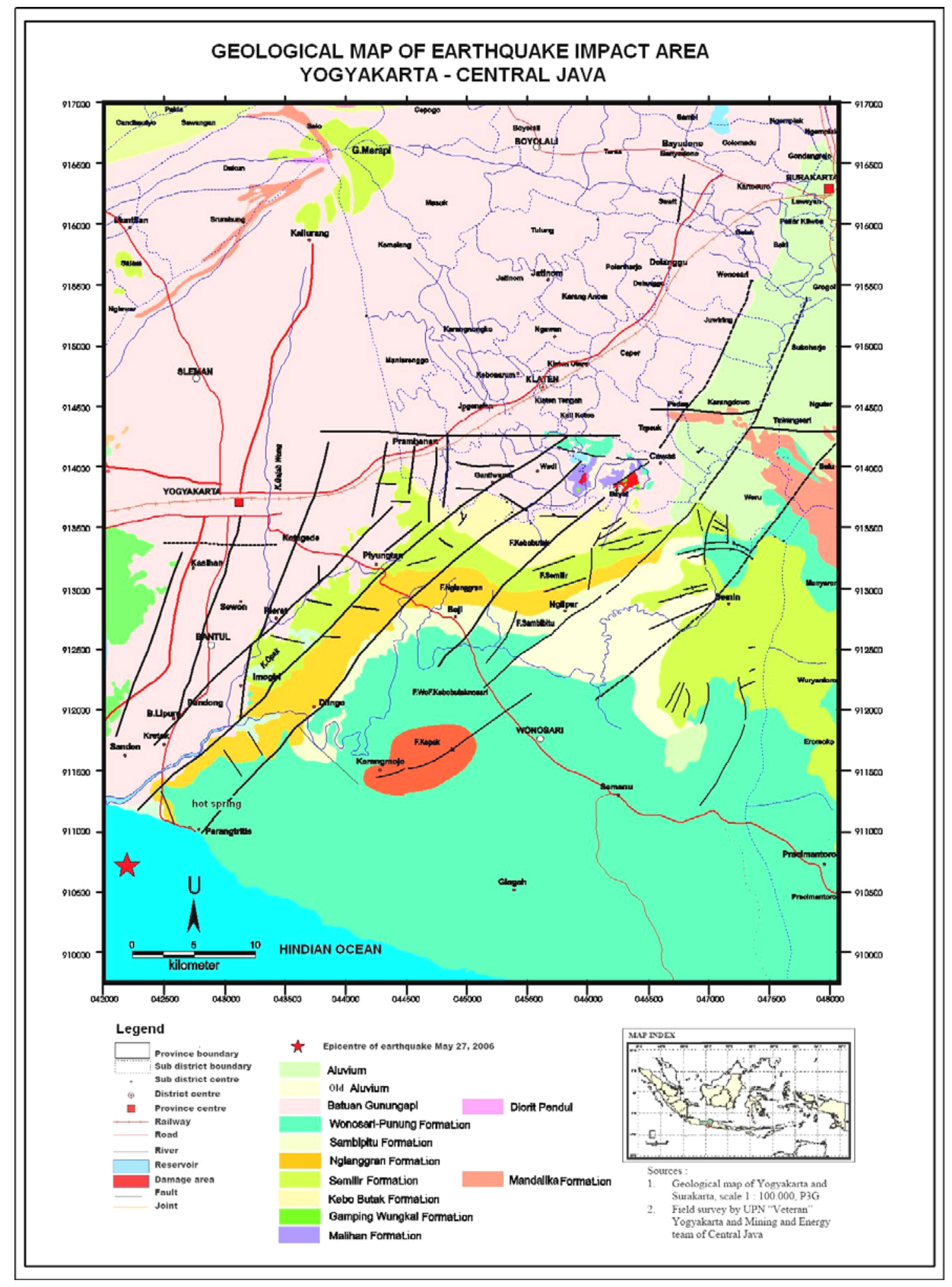

Fig.2. Geological Map of Yogyakarta and Its Surrounding (After Murwanto, et.al., 2006) 


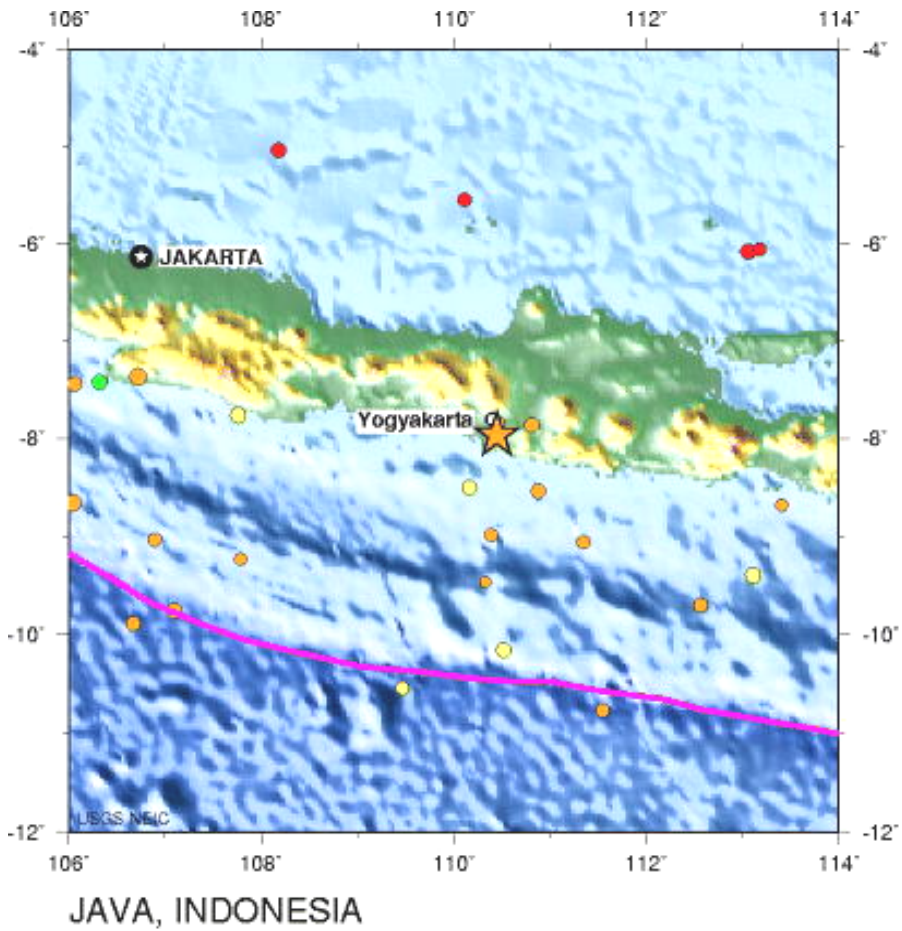

20060526 22:53:58 UTC 7.96S 110.45E Depth: 10 km, Magnitude: 6.3 Seismicity in 2006

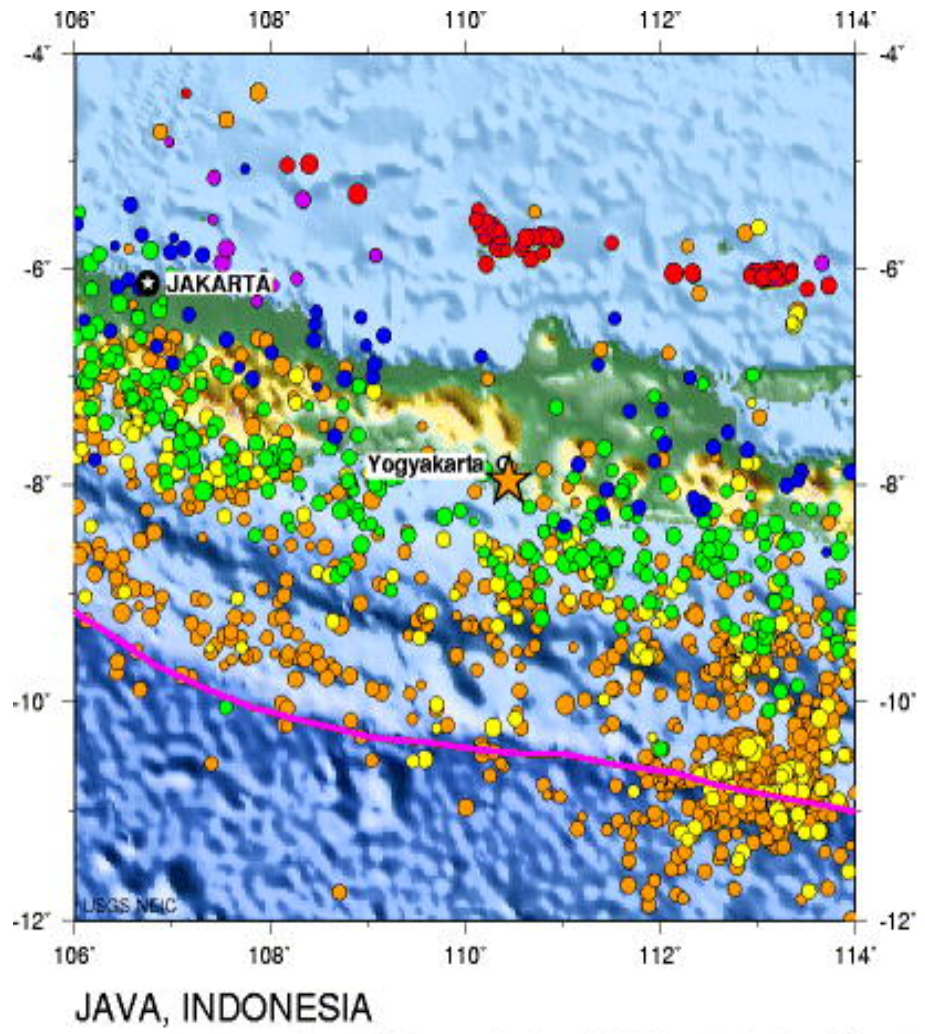

20060526 22:53:58 UTC 7.96S 110.45E Depth: 10 km, Magnitude: 6.3

Seismicity 1990 to Present

Fig. 3. Seismicity of Java Island (A. In 2006 ; B. 1990-2006) 


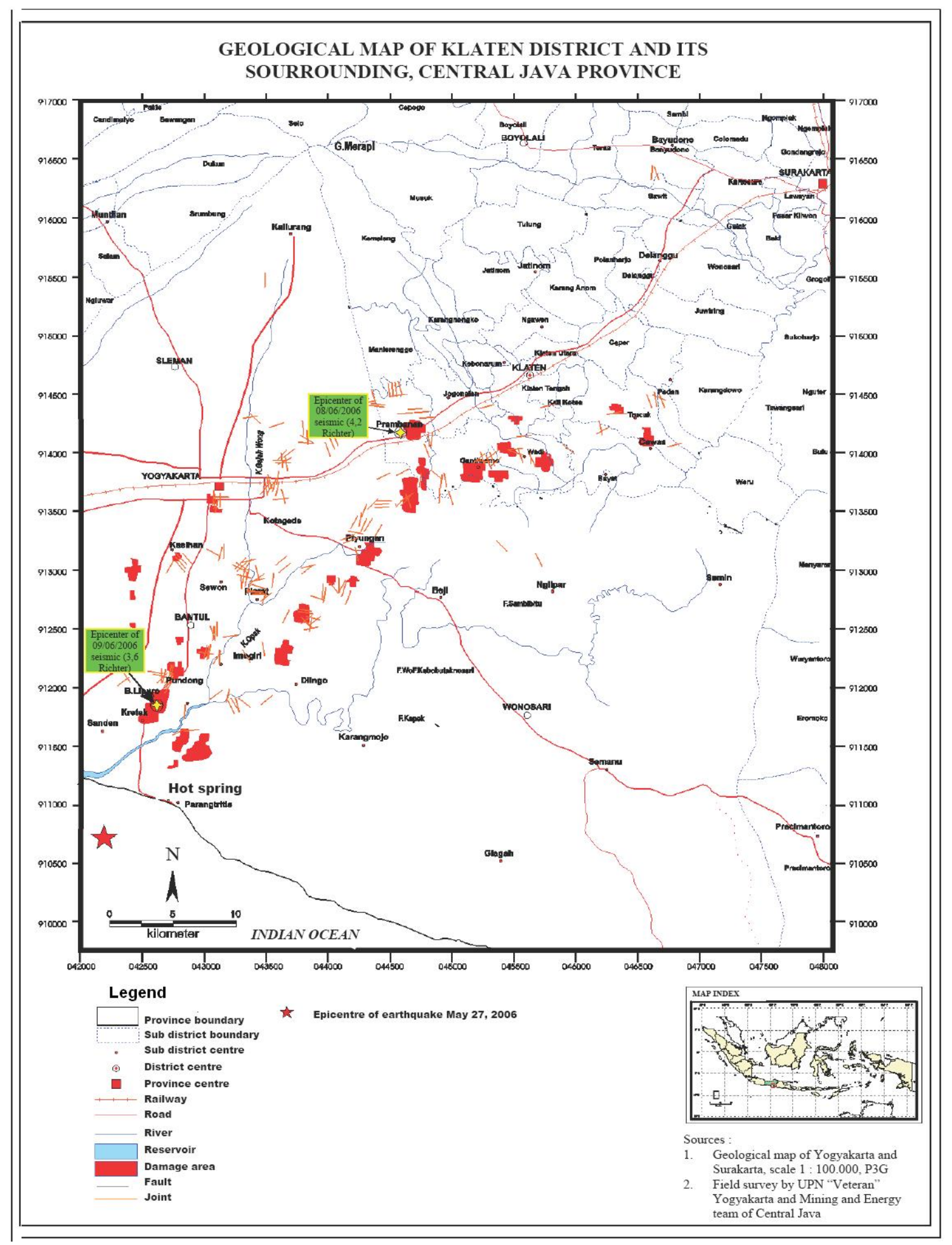

Fig. 4. Damage Area Relate to Geological Condition After $27^{\text {th }}$ May Earthquake 